\title{
Migrant mothers and the geographies of belonging
}

\author{
Mary Gilmartin $^{\mathrm{a} *}$ and Bettina Migge ${ }^{\mathrm{b} 1}$ \\ ${ }^{a}$ Department of Geography, National University of Ireland Maynooth, Maynooth, Co Kildare, \\ Ireland; ${ }^{b}$ School of Irish, Celtic Studies, Irish Folklore and Linguistics, University College Dublin, \\ Newman Building, Belfield, Dublin 4, Ireland
}

(Received 6 August 2013; accepted 14 August 2014)

\begin{abstract}
Much academic research on migrant mothers focuses on mothers who are separated from their children, often through their integration into global care chains, or on mothers within the context of family migration. This paper argues that co-resident migrant mothers' experiences provide an important window on the complexities of the migration experience. Using a specific case study of Ireland, and drawing from a broader longitudinal research project that focuses on recent migrants, the paper explores migrant mothers' understandings and experiences of belonging and notbelonging. We argue that structural obstacles and cultural understanding of care actively conspire to undermine migrant mothers' potential to develop placebelongingness. Interviewees' discussions of their status as full-time mothers were often framed through images of ideal motherhood, but equally highlighted how the absence of affordable childcare and family members isolates them and prevents them from creating a sense of belonging outside of the process of mothering and the home.
\end{abstract}

Keywords: migration; mothers; belonging; not-belonging; care; Ireland

\section{Introduction}

The ebb and flow of migration research has moved from seeing women as dependent or 'tied' migrants, to independent movers, to being one component of a mobile family unit (Cooke 2001, 2008; Kofman 2004, 2013; Morokvasic 1984). Within this, there are two distinct bodies of work that address the ways in which migration influences female subjectivity. The first highlights female empowerment as a consequence of migration, often because of the changes in economic and employment status of migrant women. The second highlights female subjugation, both as a consequence of their migration status and also because of cultural differences in the migrant destination (see Gabaccia et al. 2006; Lutz 2010 for reviews of this extensive and substantial literature). Each set of literature captures some of the complexity of migrant subjectivities, but neither provides sufficiently nuanced accounts of the multiple ways in which people understand and narrate identity, and how this changes in and through the process of migration and the experience of place.

In order to expand our understanding of the ways in which people understand and narrate identity, this article focuses on a particular group of female migrants: migrant mothers. Studies of maternal migration often focus on mothers separated from their children, involved in 'transnational mothering' as a consequence of the global care chain (for excellent examples, see Parreñas 2005; Pratt 2012). Alternatively, maternal migration is studied in the broader context of family migration, but the focus here is most often on

*Corresponding author. Email: mary.gilmartin@nuim.ie 
(male) heads of households, or on the experiences of children (for critiques, see Kofman 2004; Lutz 2010). While there is a small but growing literature on migrant fathers (see Kilkey, Plomien, and Perrons 2014), recent feminist work has paid less attention to migrant mothers (Gedalof 2009) and more to the global reorganization of reproduction (Kofman and Raghuram 2006). Yet, as we argue in this article, it is also important to pay closer attention to the experiences of co-resident migrant mothers - those who live with their children. Migration 'reveals the inherent quality of intimate relationships' (Holdsworth 2013, 82), and we suggest that being a co-resident migrant mother, as a particular and important form of intimate relationship (Erel 2009, 147), is a topic that needs further attention in migration studies. In order to develop this argument, we highlight the experiences of migrant mothers in Ireland. As a spatial context that lays claim to privileging the mother, Ireland is a particularly useful site for this examination.

In this article, we pay particular attention to place-based experiences and identities with our focus on the geographies of belonging and not-belonging for migrant mothers in Ireland. These are topics of growing interest in geography, even though this interest does not always translate into clear and precise definitions. Marco Antonsich has attempted to provide an analytical framework for belonging, and he usefully distinguishes between 'place-belongingness' and 'politics of belonging' (Antonsich 2010). Place-belongingness is affective and emotional: it refers to a sense of feeling at home. In contrast, the politics of belonging refers to socio-spatial processes of inclusion and/or exclusion. In her recent book, Nira Yuval-Davis further develops the concept of the politics of belonging. She takes a multi-scalar approach, seeing belonging in terms of religion, nationality, citizenship, cosmopolitanism and caring (Yuval-Davis 2011). The introduction of 'caring' is important here because it takes the practice of caring and locates it within a broader discussion of the politics of belonging. This ensures that caring is not just associated with the private sphere and with 'place-belongingness', but that it is also seen as fundamental to how the politics of belonging is, and might be, conceptualized and experienced. There is an extensive literature on caring and migrants, particularly centred on the global care chain. However, as Raghuram suggests, the discussion of care in migration literature is 'relatively unvariegated' (2012, 156). In her contribution, Raghuram argues for a spatially grounded and differentiated understanding of care. To this end, she incorporates the concept of the 'care diamond', which has been used to show the ways in which care is organized and delivered, through four different nodes: families/households, market, communities and state (Raghuram 2012, 163). ${ }^{2}$ Raghuram argues for the use of the care diamond in understanding the relationship between migration and care, as it shows the complexity and specificity of care more clearly than the concept of the care chain. In this article, we respond to Raghuram's call by using the care diamond as a way of thinking about the relationship between care and the politics of belonging for co-resident migrant mothers. In this way, we examine both structural and cultural understandings (Erel 2009, 8-14) of care, mothering and belonging for migrant mothers in Ireland. We argue that the caring work that is performed by migrant mothers actively works against their potential to develop a broader sense of belonging. Migrant mothers thus experience and are subjected to the politics of not-belonging, in ways that challenge their efforts to develop place-belongingness through the act of caring. In this article, we discuss the geographies of belonging and not-belonging as expressed in our interviews with migrant mothers in Ireland. We start by providing the broader context for our article and our research. 


\section{Context}

Ireland offers a fascinating site for a study of migrant mothers. The 1937 Irish Constitution makes two direct references to mothers. The first, in Article 41, claims that the state shall 'endeavour to ensure that mothers shall not be obliged by economic necessity to engage in labour to the neglect of their duties in the home' (Constitution of Ireland 1937). The second, introduced in 1983 as one of a series of divisive amendments on the issue of abortion, asserts that the right to life of an unborn child is equal to that of the child's (biological) mother. This close association of woman, motherhood and home served to spatially entrap women in Ireland, for example, through limited access to work and public space, prohibitions on contraception, divorce and abortion, and a repressive regulatory regime that punished moral transgressions (Crowley and Kitchin 2008). More recently, the Irish state has attempted to prevent pregnant women from travelling to Britain to access abortion services. Subsequent debates led to an amendment of the Irish constitution, incorporating in 1992 a specific guarantee of women's right to travel. While public and institutional suspicion of women's bodies has not waned - see the 2004 Citizenship Referendum which licensed a significant change in Irish citizenship laws following a moral panic about the figure of the 'citizenship tourist ${ }^{3}$ - local, European and global economic, social and legislative changes over the past 30 years have served to undermine the conservative status quo reflected in the Irish Constitution and recent moral panics. The lives of women in Ireland have been converging to a much greater extent with those of women in the rest of Europe. For instance, female participation in the labour force increased from 43\% to 56\% between 1996 and 2011 (McNally, Share, and Murray 2014; Turner and McMahon 2011). Paid maternity leave and subsidized parental leave times have been introduced and extended in duration. Parents also receive tax breaks and child benefit contributions and the most financially vulnerable mothers also receive additional payments such as the lone parent benefit. However, ongoing debates highlight that many issues have only been partially tackled. For instance, there has been an increase in childcare facilities in parallel with the growing participation of women in the labour force (Gallagher 2012). However, these facilities are often not affordable for parents with several children and for people with low and lower-middle incomes because childcare facilities receive no or only minimal subsidies from the state: in 2005, the Irish state spent just $0.3 \%$ of GDP on childcare services for children not in primary school, compared with an OECD average of $0.8 \%$ (Thévenon 2011, 79). While salary levels have fallen due to the economic crisis that began in 2008, childcare costs have remained static or increased making full-time care unaffordable for an increasingly larger group of people with small children. Finally, childcare regulations and supervision of facilities' compliance with them are only developing gradually in Ireland, making parents reticent about entrusting their children to these facilities. The limited support for women with children to work outside the home means that, in practice, many mothers in Ireland have few options but to be fulltime carers for their children, as envisaged by the Irish Constitution.

This article discusses the specific experiences of migrant mothers and their feelings of (not) belonging through our analysis of interviews with women with children who have recently moved to Ireland. The article is based on a more extensive study that focused on capturing the experiences of people who had moved to Ireland in recent years, either in 2004 or 2007. The study was funded by the Irish Research Council for Humanities and Social Sciences and had a longitudinal design in order to explore the dynamic nature of newcomers' experiences. We recruited participants using a variety of methods, such as distribution of flyers in public spaces like libraries, Internet cafes, migrant-focused 
organizations, snowballing and e-media. One site that we used was an online parenting forum for 'ex-pat mums and dads'. Two women contacted us following our post on this forum, and their stories made us realize that mothers, particularly of young children, faced a range of specific challenges that were not well addressed in broader research on migration to Ireland or in the research on mothers and children. In total, 11 of the 60 people who participated in the study are mothers, and two other participants became pregnant for the first time during the course of the study. Of these 13, 4 are from the USA, 3 from the UK, 2 from Germany and 1 each from Ireland, Poland, South Africa and the Netherlands. While women often had a variety of reasons for moving to Ireland, five moved to Ireland primarily to be with their Irish partners, five moved primarily because of their partner's work and the others moved for reasons of employment. The women were also diverse with respect to their social background. Seven of the women had completed a third-level degree and five had professional qualifications. Just one had secondary education only. Nine had worked in professional jobs before coming to Ireland, while three had been in third-level education. In Ireland, five engaged in paid employment, two in academic studies and two had their own businesses. Two gave up their work or training due to issues around childcare and two women created their own enterprises in order to be more flexible. In terms of their residence in Ireland, six lived in smaller urban and rural areas and seven in larger urban areas such as Dublin, Sligo and Belfast. Although several of our participants lived in Dublin, they typically lived in suburbs with relatively poor infrastructure. While our participants are clearly not among the most disadvantaged groups of migrants such as asylum seekers, illegal migrants and people on temporary work visas who have figured prominently in many publications on migration to Ireland (Loyal 2011; Luibhéid 2013), they cannot easily be defined as privileged either. Even if they have in many cases unrestricted access to the labour market due to their EU citizenship and/or due to being married to an EU citizen, many of them struggle to make a living, especially since the beginning of the recession, and have, like Irish people, had to make a range of painful changes to their lives. In many ways, our participants present a good cross section of migrants living in Ireland, most of whom originate from within the EU or from Englishspeaking countries outside the EU (e.g. the USA, Canada, Australia and New Zealand). Yet, this group of newcomers has received relatively little attention in discussions of migration in Ireland (Gilmartin and Migge 2013). Our discussion is thus innovative: it narrates the experiences/perspectives of two types of immigrants - EU and/or Englishspeaking co-resident mothers - neither of whom receive much attention in current discussions on migration.

\section{The geographies of belonging}

In this section, we discuss the various ways in which migrant mothers in Ireland describe their experiences of belonging. We focus particularly on 'home' as a form of placebelongingness, as it captures the geographies of belonging in both material and symbolic ways (Blunt and Dowling 2006). There has been a recent interest in the materiality of home-making, particularly in relation to migration (Long 2013; Tolia-Kelly 2004). Despite a growing academic interest, however, few of the women we spoke made explicit reference to home-making as a specific material act. The one person who did, a South African woman, did so in relation to a question. When asked what she would describe as home, she answered 'this house for now' (2007SA01). ${ }^{4}$ Later, she elaborated:

Interviewee: $[\ldots]$ but we try and give them the sense of stability and roots with our family traditions. And in a sense for us, I know it seems odd to some people that we, like a tortoise 
move with everything that we own and we carry it with us, but that is our safety for the children.

Interviewer: So it is things, particular kinds of photographs and mementos?

Interviewee: Yes and their stuff, all their toys and my books, those kind of things that travel with us. Some people have a base somewhere else and they live this sort of temporary life. Interviewer: So you made that decision that wherever you are that is your home?

Interviewee: Yes. (2007SA01)

Family traditions for this woman also involved food - 'the South African sweets and crisps and a couple of chocolates and things, the chips, ... and some of the cereals' - that she could purchase in a South African shop in Dublin. Yet, she was the only person who mentioned food. One other woman mentioned possessions, but in the context of deciding whether to rent or buy a place to live. ${ }^{5}$ She said that not being in her own place was the 'hardest challenge' for her, but then acknowledged that buying a house and shipping her possessions to Ireland would be a 'final decision ... if we buy it means we will be staying here for a long time' (2007UK04). For a small number of women, the act of buying a house was a symbolic marker of home-making. One woman, a returned Irish migrant, had just bought a house with her husband. She said 'it feels quite nice to have made that commitment to buy the house' (2007IR01b). However, home ownership was not necessarily a guarantee of belonging. Another woman, who lived with her husband and his brother in a house the two men had bought together before she met her husband, repeatedly commented on how she and her husband had never had a house on their 'own' (2007US06/b). Though interviews often took place in people's homes, this context was rarely mentioned by the women we spoke to. Instead, they were more likely to talk about other ways of feeling at home. One way was through the presence of animals: two people had brought dogs with them from their previous home, and another had got a dog in Ireland as a marker of belonging. Another important way was through new friendships, which were seen as crucial to establishing a connection to Ireland and to developing a sense of place-belongingness.

The women we spoke to told us of a variety of ways in which they had attempted to develop friendships in Ireland. Women with children at primary school level often highlighted the importance of their children's school as a place to meet new people. ${ }^{6}$ A woman from the UK who was living just outside Dublin suggested that making friends is a necessity for migrant women because they do not have any other support networks. Interestingly, the women who appear to be open to these new friendships were mostly other non-Irish people because they faced similar challenges.

Because with the ex pat community here [at the school] that we are involved in because all our husbands have demanding jobs that take them abroad and things like that, so you are often on your own without anybody really so making friends here as quickly as possible was essential really because when you have young children you need people sometimes. I suppose that was one of the incentives I had [...], you are driven by necessity almost because once I did start work I needed people to pick the children for me because the school was quite out in the sticks. (2007UK02)

In some cases, such self-help friendship networks developed into more structured support groups and led to the development of part-time work opportunities for the women involved. The woman from the UK, for instance, developed a cookery school which she was able to run precisely because of the help that she received from her friendship network. For women who had very small children, mother-child-based groups often fulfilled the same function as highlighted by a young American woman:

[... I I also have made friends through going to the breastfeeding group and things like that so

I have a few other friends around who are mothers from all over. [...] there is also a mother 
and toddler group every Tuesday so there are a lot of mums around with babies. [...] (2007US04)

But often women were also bonded because they found themselves in a similar situation and thus struck up friendships. So the American woman also told us that she made friends with other women with small children who were living in the same apartment complex: 'The girl across the hall had a baby a couple of months before I did so we kind of are friends, and there is another girl who had a baby around the same time so we all became friends' (2007US04). Women with very young children also made use of online parenting groups and other Internet fora to find out about things and to create a sense of place-belongingness. As a young mother from the USA commented:

I mean I couldn't imagine life without the Internet to be honest, like rollercoaster and different sites, they just help with everything, questions answered, there is always someone who needs help and you can help them. I think there are some great websites out there for parents in Ireland. (2007US06)

The website had, in this instance, led to a close friendship with another young woman from the USA who had recently had a baby in Ireland, and the two women meet up regularly for lunch. Besides these support networks that catered to the specific needs of women with (small) children, women also negotiated other relationships such as with (previous) co-workers and especially in the case of women with Irish partners with his friends and their partners (2007US04, 2007US06, 2007SA01). Women with Irish partners often also engaged in new ways with their Irish in-laws once they had children. Most of our female interviewees found their Irish in-laws welcoming and women with children in particular often asserted that they found them to be supportive. One young woman from the USA, for instance, spoke very positively of her parents-in-law:

They are definitely very supportive, ever since they found out that we were having a baby they have been very supportive, money wise, anything that we need because they know that it is a struggle. So in that way they have been very accommodating. (2007US04)

However, few of the interviewees gave the impression that relations with in-laws were entirely based on mutual liking; most of them seem to be predicated on mutual needs. As a consequence, long-distance friendships and friendships with other migrants in Ireland were seen as very important.

The interviews with migrant mothers suggest that, contrary to the literature on homemaking (Long 2013; Tolia-Kelly 2004), human relationships rather than material objects are central to people's feelings of belonging in Ireland. While the women we spoke to asserted the importance of family relationships for their lives, they foregrounded friends, rather than family, as central to their everyday lives in Ireland. The centrality of friendships appears to be related to the lack of adequate structural support for people with children in Ireland. In order to fill this gap, migrant mothers, unlike their indigenous peers who rely on family-based support, invest in friendships and technologically mediated relationships to build up support networks. While these networks appear to provide effective solutions to their everyday problems, they also highlight broader issues about the process of integration. They demonstrate the exclusionary practices of the indigenous Irish population: migrant women are rarely able to participate in the same networks as Irish women because the latter, especially if they are from the local area, rely on their family networks and are less open to contacts with newcomers. In a sense, this also increases the vulnerability of migrant women because they have to build up these networks at the time when they also require support. At least in the short term, this could lead to social isolation. As we found, belonging has a range of different meanings for the mothers we spoke to, and these meanings had certainly 
been affected by their experiences of both migration and motherhood. As Ralph and Staeheli comment, 'the syntax of belonging ... is structured by relationships and practices in a variety of locations' $(2011,526)$. Their observation is equally pertinent for understanding not-belonging, which is the focus of the next section.

\section{The geographies of not-belonging: families and work}

The migrant mothers who spoke to us highlighted home and friendships as important in creating a sense of belonging. These are directly related to two aspects of the care diamond: families and communities. However, the relationship with families and communities also foregrounded experiences of not-belonging, though not-belonging was exacerbated by the state and by markets, the other aspects of the care diamond. In our analysis of the ways in which migrant mothers described their sense of not-belonging, two topics emerged as of particular importance. The first relates to families, while the second relates to work. The interconnections of families and work as sites of not-belonging provide a powerful illustration of the relationship between care and mothering and the politics of belonging.

Many of the women we met spoke about their sadness at being separated from their parents and siblings - particularly their mothers - at this time in their lives. A young German woman who was pregnant when we interviewed her for the second time spoke about how her pregnancy made her feel even more detached from Ireland. She explained it in terms of family: 'you want to be with your parents and your sisters, that is the main issue and maybe because everything is so new' (2007GER02b). A number of women who had already given birth mentioned how they missed immediate emotional and practical support from their mothers. One woman said, of giving birth to her first child, that 'I was missing my mother acutely' (2007SA01). Another said that the absence of her mother in the time after her first child was born had led her to consider where she might give birth in the future, commenting that 'so I think if I had another I might have the baby back home' (2007US06). Women mentioned regular travel - both to and from Ireland - as a way of ensuring that family relationships were nurtured. However, travel became more difficult as parents or children got older, either because of time constraints imposed by school attendance or the expense of international travel, so other forms of communication telephone, email or Skype, for example - were also important means of staying in touch. However, for many of the women we met, these long-distance affective relationships were unsatisfactory primarily because they placed limits on the amount and quality of care their (female) family members could provide to them.

The emphasis on the provision of care by family members needs to be understood in the broader landscape of childcare in Ireland. While there have been some recent efforts to expand the provision of childcare in Ireland (Gallagher 2012), relatives continue to be a very important source of childcare for pre- and primary-school age children in Ireland (Share and Kerrins 2009, 33). Grandparents play a crucial role in this: as Share and Kerrins comment, 'grandparents fill the gaps in child care provision' $(2009,39)$. Women with Irish partners often availed of help from their partner's family. Sometimes this was on a reciprocal basis. For example, a young woman from the USA described her arrangement with her sister-in-law, saying:

Yes she [sister-in-law] will take [my daughter]. We had a wedding to go to a couple of weeks ago so she had [my daughter] for 2 days and then I take the kids pretty often so it makes it fair and I don't mind having the kids around especially if [my husband] is working Friday nights so it is kind of nice to have the kids around. (2007US06) 
More often, though, the reliance on Irish in-laws for support with care forced mothers into closer relationships with their partner's family, and this was often a source of tension and irritation. As a woman from the USA said of her in-laws, who lived close by: 'they are family, but I don't feel like they are my family, I don't want them to be my family' (2007US05). While she was quite vocal about the difficulties she experienced with her inlaws, others were more circumspect. One young woman from the USA spoke very positively of the financial support provided by her parents-in-law, but described her interaction with them as predicated on her son, their only grandchild:

I would go over there because of course they like to see [my son], so I would, occasionally if his mum asks me, do you want to go to town, I will go to town with her and we will go shopping. Or she would baby sit [my son] during the week if I need to do something. I mean I wouldn't go over there everyday and just sit and have a chat, but occasionally. (2007US04)

Indeed, all of the women with Irish partners spoke of their conflicted relationships with their partners' families, ranging from their desire for limited interaction to outright avoidance and dislike.

Other women lived far away from their families and were reliant on other forms of childcare. Their experiences of childcare in Ireland were often shaped by their experiences in their countries of origin. So, for women from other European countries where childcare is often provided by the state, the lack of availability of state-provided childcare in Ireland was a recurrent theme. A Dutch woman, married to an Irish man, was most vociferous about state failings in this regard:

they so don't stimulate women in the workplace and they almost force you to give up your job instead of trying to help you and support you and keep you in your job. And then there are no women in government and there are no women in senior positions, well because there are no childcare facilities and there is no flexibility and there is no financial support for that. (2004NL01)

The reliance on private, marketized childcare meant that the cost of childcare was a significant issue for women with young children, and an issue they were very aware of and spoke about openly. Many felt that they had to balance the cost of childcare with their likely earnings and that this would prevent them from returning to work. A young Polish woman thought that she might get her mother to come to Ireland and look after her child so she could return to work (2004POL06b), a phenomenon described as 'flying grandmothers' in the UK (Kilkey, Plomien, and Perrons 2014, 186). A woman from the UK said she couldn't work during her children's summer holidays 'because then I have child care costs' (2007UK02b). Her part-time work during term-time, with a relocation agency, involved such irregular hours that she usually relied on friends to help out. This reliance on networks of friends was common among women who had moved to Ireland because of their partner's work, but often it took time to build these networks. Friends were also more likely to provide help in the daytime, but not in the evenings or at weekends. As women without family in Ireland struggled to find babysitters, the result was more limited opportunities for social time with their partners. As a South African woman told us, 'especially with young kids in the family then you can't go out in the evenings very much, it took us a long time to figure out about baby sitting and things like that' (2007SA01). This was echoed by the UK woman who said that it took her a while to find a babysitter, and in the end, she asked neighbours for recommendations, rather than advertising in a supermarket (2007UK02). This woman also commented that this 'is an issue for other ex pats that they can't go out for the first few months until they find a baby sitter that they know is reliable' (2007UK02). Though this appeared to happen over time, it often took much longer than people initially hoped for and often led to a sense of 
loneliness and isolation, as well as taking a toll on adult relationships. It also made it difficult for women to find time on their own, and many spoke of their desire for time away from their children, as well as the obstacles they encountered in making that happen.

Difficulties in accessing affordable childcare meant that many of the women we met, particularly those with young children, were full-time mothers. In their work with young Polish mothers in London, Ryan et al. found that many 'welcomed the opportunity to be full-time mothers' $(2009,68)$. We found some similar sentiments in Ireland, among women from a range of educational and employment backgrounds, though this was often discursively framed in terms of broader societal pressures over ideal motherhood and the importance of stay-at-home mothers (Dillaway and Pare 2008). A UK mother of two, who had resigned her professional job when she moved to Ireland because of her husband's promotion, said:

I love being there for them. ... I really had a terrible trauma with putting them in childcare when they were babies and I was working. I would send them when they weren't really well and things because it would put me under pressure ... I always felt a bit disapproved of at work if I took time off. And with two of them there were often times when they were sick .... So I always was on a permanent guilt trip that I was being a bad mum or a bad employee, so now I just enjoy the luxury of not having that cost and dilemma. (2007UK02B)

A young woman from the USA told us 'I do like being a stay at home mum, I couldn't imagine putting her in a crèche or anything like that and just bonding and spending time with her. I couldn't imagine missing out on that' (2007US06). Another young woman from the USA, who was unable to complete her postgraduate studies when she became pregnant, said of her time as a stay-at-home mother:

Well I am not going to lie, I do feel like I am missing out a little bit on what I could be doing with my life, but he won't be young for so long and I understand that and I value the time that I get to spend time with him and I also value not having to work because I have friends who have kids who work and they are very stressed out. (2007US04)

Meanwhile, women who did not speak English as a first language welcomed the opportunity to teach their children their language and cultural norms. Yet, as illustrated by the young woman from the USA, many stay-at-home mothers were ambivalent about their situation. When they spoke favourably about their situation, it was often through comparison with other mothers, who they saw as having no choice but to work. At the same time, many also expressed a sense of being isolated or de-skilled, and they also spoke about missing work. An Italian woman who had just given birth to her first child spoke about wanting a break from 'kids-related discussions' with other mothers (2007IT04b). A South African woman, who is a trained graphic designer, has had limited opportunity to work in Ireland. This is partly because of her youngest child's developmental disability, but partly because of the difficulties in making professional contacts and getting freelance work because of the constraints imposed by childcare responsibilities. 'I do miss [work] terribly,' she said (2007SA01). The women who commented on missing work were not only those with highly skilled jobs and career ambitions. This ambivalence towards fulltime mothering was common among women of all nationalities and skills levels and may be accentuated by women's experiences as migrants (Madianou 2012).

Though many of the women we spoke to were, at the time, stay-at-home mothers, they generally saw this as a temporary arrangement, expressing a strong desire to return to or continue working in the future. Some had already managed to combine motherhood and work, such as the US woman who had set up her own business, or the UK woman who, despite saying that she was a stay-at-home mother, had two part-time jobs. For the woman from the USA, running her own business was intimately connected to becoming a mother: 
Interviewee: ... Because my incentive was to be just financially independent so he takes care of basics, I can take care of my trips home and savings for the kids for school which is really important if they wanted to go to America or here or whatever.

Interviewer: So this is your way of getting independence for yourself.

Interviewee: Yes. (2007US05)

Later, she said:

And it is not money, I am just interested in creating financial independence because no one can tell you what to do when you have your own money, no one, not your boss, not your husband, nobody, you have your own choices and at this point in my life that is what I am really striving for. And it is not money it is just the freedom of choice because without it you have no choice. (2007US05)

Women with older children had also managed to find work, though not always in their area of expertise. A UK woman with two older children had started part-time work as a hotel receptionist, though she had previously worked as a research assistant/interviewer in a large urban hospital in Canada (2007UK04). An older US woman worked as an office assistant, though her training and experience were in graphic design (2007US03). Women with younger children spoke of their plans for when their children were older, such as the business graduate who was retraining in horticulture (2007US04b), or the Irish woman with a sales and marketing background, who spoke of developing an arts and crafts café for young children (2007IR01). In these ways, the experiences of these migrant women in Ireland are not unusual. For example, Boyle, Feng, and Gayle (2009) highlight how family migration has a negative impact on women's experiences of employment. Research suggests that having children is a contributing factor in the deskilling of migrant women in Switzerland (Riaňo and Baghdadi 2007) and in exclusion from the workforce in Denmark (Liversage 2009). ${ }^{7}$ As Aure points out in a study of skilled dependent migrants in Norway, the withdrawal of migrant women from the labour market for the purposes of child-bearing and child-rearing may be compatible with gendered expectations, but serves to "make women more vulnerable and economically dependent and may work as a "honey trap"' (Aure 2013, 282). However, in the Irish context, migrant women also had to negotiate a labour market that had been highly masculinized for many decades, and that was described as a 'private patriarchy' as recently as the mid-1990s (Mahon 1994). Though female participation in the workforce has increased significantly, from $43 \%$ to 56\% between 1996 and 2011, this employment is polarized, with inequalities experienced by women in both high- and less-skilled employment (McNally, Share, and Murray 2014; Turner and McMahon 2011). Despite increased levels of workforce participation, women also continue to take the majority share of childcare and housework (James 2011, 664). However, none of the women we spoke to expressed a desire to remain as a stay-at-home parent in the long term, and some were very conflicted about what it would mean for their sense of identity. This was a recurrent theme in an interview with a Dutch woman with two young children who was facing redundancy and a planned move to rural Ireland. At the start of our first interview, she said 'I have always worked so I feel very strange about giving up my job, I have always had my own financial independence and I like working' (2004NL01). She returned to this topic again at the end of the interview, saying

I am a little bit apprehensive about being a stay at home mum, I do it now because I am on maternity leave and I love it because you know it is fine and you go back to work. But now that that is going to change I am a little bit apprehensive about that. (2004NL01)

When we met her a second time, she had been looking for jobs but had not been successful, and was frustrated with what she perceived as a lack of support for mothers to return to work. As she said, 'I don't want someone else to raise my children for me, but 
then I also want to work so where is the balance?' (2004NL01b). For many women, it appeared that the only way in which they could re-enter the workforce was to create their own employment. There is a growing awareness of so-called 'mumpreneurs' (Ekinsmyth 2013), but this rarely highlights migrant women, in contrast to a broader focus on entrepreneurship among migrant men (Kloosterman and Rath 2003). Yet, among the women we met, many spoke about being entrepreneurial as a way of overcoming the structural barriers to employment in Ireland for migrant mothers. This was particularly the case for women who had moved to Ireland because of their partners' work, in contrast to stereotypical depictions of 'trailing spouses'.

The experiences of not-belonging, as recounted by the women we met, centred on families and work in the broader context of care and care-giving. In many ways, the daily experience of caring, particularly for younger children, heightened women's sense of notbelonging and apartness. It made them keenly aware of the distance from their broader families, which in turn limited their options for childcare support, which in turn restricted their possibilities for working. In this way, migrant mothers experienced not-belonging because of the particular configuration of the care diamond in the context of Ireland. The limited role of the state in childcare provision, and the increasing marketization of childcare, means that access to childcare in Ireland more generally is restricted and expensive: the intersections of markets and state thus create difficult conditions for equitable access to childcare. In Irish society, these difficulties are overcome through the use of families and communities, particularly grandparents and local people who act as childminders in the child's home (McNally, Share, and Murray 2014). For migrants, particularly recent migrants, this is not a clear option. As our participants showed, many were without extended family support, and struggled to build communities in the shorter term. While women used cultural arguments to justify their roles as full-time mothers, often centred on images of ideal motherhood, their stories simultaneously revealed the structural obstacles to belonging for migrant women, particularly in relation to work.

\section{Conclusion: new geographies of belonging?}

The migrant mothers we interviewed in Ireland describe 'belonging' as a web of familiar people, practices and networks. They make a considerable effort to engage with Ireland, but they are also ambivalent about it - ranging from concerns about the treatment of women, to issues with creating strong and lasting networks of belonging. Their ambivalence about Ireland and their difficulties in creating place-belongingness in Ireland appear greater than for people without children who we also interviewed as part of the broader study. Many of the mothers cannot actively participate in Irish society because of a relative absence of affordable childcare and alternative structures, notably the family as a support system. This absence of support structures does not allow them to participate in the work market, an important place where local women and newcomers without children create belonging. They thus disproportionally depend on friendships with other women in similar circumstances to accomplish their everyday lives. However, paradoxically, this does not generally allow them to create close links with Irish people either because most Irish mothers rely on family-based support networks. As a result, many of the women with children who we interviewed formed complex support networks with other migrant women. While these networks appear to be highly effective, they also prevent these women from fully integrating into Irish society. This situation has led many of the women we interviewed to engage more urgently in a critical reflection about the meaning of belonging and their feeling about Ireland and their country of origin in general. 
Though our focus is on belonging, the women we spoke to illustrated, in a very grounded way, the care diamond approach recently advocated by Raghuram (2012). This argues for a greater geographical sensitivity to care, specifically paying attention to how relationships between the four different aspects of the care diamond - families, market, civil society and the state - differ across spatial contexts. The stories that the women we met shared with us centred on care because as parents of dependent children their lives are structured by the nature and availability of care options. In contrast to much of the academic literature on care and migration, their caring took place in situ: in most cases they lived with their children, and the need to care for their children, and for their families, was pressing. Yet, they received limited support in this role, and had to work hard to develop their own support networks and their own ways of coping, often at great personal cost. This was particularly obvious in relation to employment, as many mothers - particularly of younger children - felt they were unable to work because of the difficulties in accessing childcare. In these ways, their ethics of care restricted their possibilities for belonging. Excluded from work environments, and with limited or no family support, they were forced into defining themselves primarily as mothers in a context where mothers are assigned a specific, and restricted, role and had limited options to forge connections with Ireland outside of networks related to mothering and caring. The realities of life for many migrant mothers thus come into conflict with a broader politics of belonging in Ireland that frames mobile women as problematic and potentially threatening, and that marks the space of mothers as the home. In this context, migrant mothers in Ireland are compelled to negotiate the simultaneous processes of belonging and not-belonging in their everyday lives, demonstrating how 'people cannot be simply defined, in most situations, as either belonging or not belonging' (Yuval-Davis 2011, 200). As our research shows, their efforts to do so are inventive and often inclusive and range across a wide variety of locations. However, they also demonstrate how the caring work of migrant mothers, while discursively supported by the Irish state, is not practically supported, often to the detriment of the geographies of belonging for migrant mothers.

\section{Acknowledgements}

We acknowledge the Irish Research Council for Humanities and Social Sciences and the research assistance of Elaine Burroughs and Owen McCarney. An earlier version of this paper was presented at an ESF Conference on 'Home, Migration and the City' in Sweden in August 2010, and we are grateful to the organizers of that conference, Ayona Datta and Kathy Burrell, and the other conference attendees, for their observations and insights. We also thank the anonymous reviewers of this paper who made very helpful suggestions for improvement. We particularly thank the research participants for sharing their stories about life in Ireland with us.

\section{Disclosure statement}

No potential conflict of interest was reported by the authors.

\section{Funding}

This paper was based on a broader research project entitled "Towards a dynamic approach to research on migration and integration" funded by the Irish Research Council for Humanities and Social Sciences.

\section{Notes}

1. Email: bettinamigge@ucd.ie

2. Raghuram takes this term from the work of Shahra Razavi, who describes the care diamond as 'the architecture through which care is provided' $(2007,21)$. 
3. The term 'citizenship tourist' was used to describe a pregnant woman coming to Ireland primarily for the purposes of giving birth (White and Gilmartin 2008).

4. Interviewees are identified by the year of arrival (either 2004 or 2007), nationality (USA, UK, GER, IR, SA, POL, GER) and a numeric identifier. Second interviews are indicated by the use of ' $b$ '.

5. In Ireland, rental accommodation is typically furnished, so it can be difficult to set up home with personal possessions in a rented apartment or house.

6. In Ireland, it is customary for parents to accompany their children to school during most of their time at primary school.

7. In Denmark, this was primarily because having children limited the options for migrant women to learn Danish. Language proficiency was not an issue for the women who participated in our research.

\section{Notes on contributors}

Mary Gilmartin is a Senior Lecturer in the Department of Geography at the National University of Ireland Maynooth. Her recent research focuses on the geographies of contemporary migration to and from Ireland, and on theorizations of migration. She recently co-edited Migrations - Ireland in a Global World (Manchester University Press, 2013, with Allen White).

Bettina Migge is an Associate Professor in Linguistics at University College Dublin. Her research interests include sociolinguistics, language contact, and language and migration, and she has published widely on questions of language contact and language use among migrant populations. Her recent book on Exploring Language in a Multilingual Context (with Isabelle Léglise) was published by Cambridge University Press in 2012.

\section{References}

Antonsich, Marco. 2010. "Searching for Belonging - An Analytical Framework." Geography Compass 4 (6): 644-659.

Aure, Marit. 2013. "Highly Skilled Dependent Migrants Entering the Labour Market: Gender and Place in Skill Transfer." Geoforum 45: 275-284.

Blunt, Alison, and Robyn Dowling. 2006. Home. London: Routledge.

Boyle, Paul, Zhiqiang Feng, and Vernon Gayle. 2009. "A New look at Family Migration and Women's Employment Status." Journal of Marriage and Family 71 (2): 417-431.

Constitution of Ireland. 1937. Article 41.2.2 (On the family).

Cooke, Thomas J. 2001. “'Trailing Wife' or 'Trailing Mother'? The Effect of Parental Status on the Relationship Between Family Migration and the Labor-Market Participation of Married Women." Environment and Planning A 33: 419-430.

Cooke, Thomas J. 2008. "Migration in a Family Way." Population, Space and Place 14: 255-265.

Crowley, Úna, and Rob Kitchin. 2008. "Producing 'Decent Girls': Governmentality and the Moral Geographies of Sexual Conduct in Ireland (1922-1937)." Gender, Place and Culture 15 (4): $355-372$.

Dillaway, Heather, and Elizabeth Paré. 2008. "Locating Mothers: How Cultural Debates About Stayat-Home Versus Working Mothers Define Women and Home.” Journal of Family Issues 29 (4): 437-464.

Ekinsmyth, Carol. 2013. "Mothers' Business, Work/Life and the Politics of 'Mumpreneurship'." Gender, Place and Culture. doi:10.1080/0966369X.2013.817975

Erel, Umut. 2009. Migrant Women Transforming Citizenship: Life Stories from Britain and Germany. Farnham: Ashgate.

Gabaccia, Donna, Katharine M. Donato, Jennifer Holdaway, Martin Manalansan, and Patricia Pessar, eds. 2006. "Special Issue: Gender and Migration Revisited." International Migration Review 40 (1): 3-249.

Gallagher, Aisling. 2012. "Neoliberal Governmentality and the Respatialisation of Childcare in Ireland." Geoforum 43 (3): 464-471.

Gedalof, Irene. 2009. "Birth, Belonging and Migrant Mothers: Narratives of Reproduction in Feminist Migration Studies." Feminist Review 93: 81-100. 
Gilmartin, Mary, and Bettina Migge. 2013. "European Migrants in Ireland: Pathways to Integration." European Urban and Regional Studies. doi:10.1177.0969776412474583

Holdsworth, Clare. 2013. Family and Intimate Mobilities. Basingstoke: Palgrave Macmillan.

James, Al. 2011. "Work-Life (Im)'balance' and Its Consequences for Everyday Learning and Innovation in the New Economy: Evidence from the Irish IT Sector." Gender, Place and Culture 18 (5): 655-684.

Kilkey, Majella, Ania Plomien, and Diane Perrons. 2014. “Migrant Men's Fathering Narratives, Practices and Projects in National and Transnational Spaces: Recent Polish Male Migrants to London." International Migration 52 (1): 178-191.

Kloosterman, Robert, and Jan Rath, eds. 2003. Immigrant Entrepreneurs: Venturing Abroad in the Age of Globalization. Oxford: Berg.

Kofman, Eleonore. 2004. "Gendered Global Migrations." International Feminist Journal of Politics 6 (4): 643-665.

Kofman, Eleonore. 2013. “"Gendered Labour Migrations in Europe and Emblematic Migratory Figures." Journal of Ethnic and Migration Studies 39 (4): 579-600.

Kofman, Eleonore, and Parvati Raghuram. 2006. "Gender and Global Labour Markets: Incorporating Skilled Workers." Antipode 38: 282-303.

Liversage, Anika. 2009. "Life Below a 'Language Threshold': Stories of Turkish Marriage Migrant Women in Denmark." European Journal of Women's Studies 16 (3): 229-247.

Long, Joanna C. 2013. "Diasporic Dwelling: The Poetics of Domestic Space." Gender, Place and Culture 20 (3): 329-345.

Loyal, Steven. 2011. Understanding Immigration in Ireland: State, Labour and Capital in a Global Age. Manchester: Manchester University Press.

Luibhéid, Eithne. 2013. Pregnant on Arrival: Making the Illegal Immigrant. Minneapolis: University of Minnesota Press.

Lutz, Helma. 2010. "Gender in the Migratory Process." Journal of Ethnic and Migration Studies 36 (10): $1647-1663$.

Madianou, Mirca. 2012. "Migration and the Accentuated Ambivalence of Motherhood: The Role of ICTs in Filipino Transnational Families." Global Networks 12 (3): 277-295.

Mahon, Evelyn. 1994. "Ireland: A Private Patriarchy?" Environment and Planning A 26 (8): 1277-1296.

McNally, Sinéad, Michelle Share, and Aisling Murray. 2014. "Prevalence and Predictors of Grandparent Childcare in Ireland: Findings from a Nationally Representative Sample of Infants and Their Families." Child Care in Practice 20 (2): 182-193.

Morokvaśic, Mirjana. 1984. "Birds of Passage are Also Women ...." International Migration Review 18 (4): 886-907.

Parreñas, Rhacel. 2005. "Long Distance Intimacy: Class, Gender and Intergenerational Relations Between Mothers and Children in Filipino Transnational Families." Global Networks 5 (4): 317-336.

Pratt, Geraldine. 2012. Families Apart: Migrant Mothers and the Conflicts of Labor and Love. Minneapolis: University of Minnesota Press.

Raghuram, Parvati. 2012. "Global Care, Local Configurations \& Challenges to Conceptualizations of Care." Global Networks 12 (2): 155-174.

Ralph, David, and Lynn Staeheli. 2011. "Home and Migration: Mobilities, Belongings and Identities." Geography Compass 5 (7): 517-530.

Razavi, Shahra. 2007. The Political and Social Economy of Care in a Development Context: Conceptual Issues, Research Questions and Policy Options. Gender and Development Programme Paper No. 3. United Nations Research Institute for Social Development.

Riaňo, Yvonne, and Nadia Baghdadi. 2007. "Understanding the Labour Market Participation of Skilled Immigrant Women in Switzerland: The Interplay of Class, Ethnicity, and Gender." Journal of International Migration and Integration 8: 163-183.

Ryan, Louise, Rosemary Sales, Mary Tilki, and Bernadette Siara. 2009. "Family Strategies and Transnational Migration: Recent Polish Migrants in London." Journal of Ethnic and Migration Studies 35 (1): 61-77.

Share, Michelle, and Liz Kerrins. 2009. "The Role of Grandparents in Childcare in Ireland: Towards a Research Agenda." Irish Journal of Applied Social Studies 9 (1): 33-47.

Thévenon, Olivier. 2011. "Family Policies in OECD Countries: A Comparative Analysis." Population and Development Review 37 (1): 57-87. 
Tolia-Kelly, Divya. 2004. "Locating Processes of Identification: Studying the Precipitates of ReMemory Through Artefacts in the British Asian Home." Transactions of the Institute of British Geographers 29 (3): 314-329.

Turner, Thomas, and Juliette McMahon. 2011. "Women's Occupational Trends in the Irish Economy: Moving Towards High-Skilled Occupations or Evidence of Deskilling." Gender, Work and Organization 18 (Suppl 1): e222-e240.

White, Allen, and Mary Gilmartin. 2008. "Critical Geographies of Citizenship and Belonging in Ireland." Women's Studies International Forum 31: 390-399.

Yuval-Davis, Nira. 2011. The Politics of Belonging. London: Sage.

\section{ABSTRACT TRANSLATIONS}

\section{Madres migrantes y las geografías de la pertenencia}

Gran parte de la investigación científica en madres migrantes se centra en las madres que son separadas de sus niñxs, a menudo a través de su integración a las cadenas de cuidado global, o en madres dentro del contexto de la migración de la familia. Este trabajo sostiene que las experiencias de las madres migrantes co-residentes nos brindan una importante ventana por la cual observar las complejidades de la experiencia de migración. Utilizando un estudio de caso específico de Irlanda, y basándose en un proyecto de investigación longitudinal más amplio que se centra en migrantes recientes, este trabajo explora las formas de entender y las experiencias que las madres migrantes tienen sobre la pertenencia y la no pertenencia. Sostenemos que los obstáculos estructurales y las formas culturales de entender el cuidado conspiran activamente para socavar el potencial de las madres migrantes para desarrollar su pertenencia al lugar. Las discusiones de las entrevistadas sobre su estatus como madres a tiempo completo a menudo fueron enmarcadas a través de imágenes de maternidad ideal, pero igualmente destacaron cómo la ausencia de lugares accesibles donde dejar a sus niños y de los miembros de su familia las aislaba y les impedía crear un sentido de pertenencia fuera del proceso de la maternidad y el hogar.

Palabras claves: migración; madres; pertenencia; no-pertenencia; cuidado; Irlanda

\section{移民母亲与归属感的地理}

已有诸多针对移民母亲的学术研究, 聚焦经常是经由整合进全球照护链而与孩子 分离的母亲, 或是全家移民脉络中的母亲。本文主张, 移民母亲共同居住的经 验, 对于移民经验的复杂性, 提供了重要的理解窗口。本文运用一特定的爱尔兰 案例研究, 并使用聚焦晚近移民的更广泛的长程研究计画，探讨移民母亲对于归 属感与缺乏归属感的理解和经验。我们主张，结构性的障碍，以及对照护工作的 文化理解, 主动且共同导致了侵蚀移民母亲建立地方归属感的潜力。受访者对于 其做为全职母亲的身份之讨论，经常透过理想的母职意象框架之，却也同样强 调，缺乏可负担的育儿照料和家庭成员的不在场，使她们受到孤立，并使其无法 在母职过程和家庭之外创造归属感。

关键词 : 移民; 母亲; 归属感; 缺乏归属; 照护; 爱尔兰 